Pakistan Journal of Humanities \& Social Sciences Research Volume No. 02, Issue No. 01(June, 2019)

\title{
"COMPARATIVE STUDY OF DEPRESSION AND PROCRASTINATION AMONG CLINICALLY DIAGNOSED DEPRESSIVE PATIENTS AND GENERAL POPULATION OF PUNJAB"
}

\begin{abstract}
Hifsa Batool*, Abid Masood Khan** \& Nosheen Saba $†$ Abstract

The objective of current study is to explore prevalence of depression and procrastination among general population who never visited any hospital or any other place for management of their sadistic life and to compare level of depression among clinically diagnosed depressive patients and general population of Punjab. It was core objective of study to explore whether procrastination is the cause of depression and for this purpose relationship between depression and procrastination is made. The sample $N=240$ comprised of 120 depressive individuals $(60=$ male, $60=$ female $)$ and 120 individual from general population $(60=$ male and $60=$ female $)$ living in Lahore, Multan and Faisalabad cities were selected through Purposive and snow ball sampling technique from different hospitals and residential areas. Beck depression inventory (BDI) by Aaron.T.Beck, (1971) and procrastination scale by Tuck man, (1991) were used as tools of the study. It was found out that depression is positively correlated with procrastination. Level of depression is high among married as compared to unmarried and Level of depression is high in males as compared to females. The level of procrastination is less in females as compared to males. Level of procrastination is low among unmarried as compared to married.
\end{abstract}

Key words: Procrastination, depression, depressive individuals, non depressive individuals, Punjab.

*Govt. Special Education Department Punjab Email:

hifsa763@gmail.com

**Govt. Special Education Department Punjab Email:

abidmasood1986@gmail.com

$\dagger$ Govt. Special Education Department Punjab Email:

nosheensaba3@gmail.com 


\section{INTRODUCTION}

Individuals these days are passing through major health problems. They experience feelings of sadness, gloominess or melancholy. Depression results when this state of mind stands for a long time span. It can affect individual capacity to work proficiently. It is an ailment that entraps mind, body and belief system. It distresses the mannerisms and routine of life, the way of thinking individually and collectively as beneficial member of healthy society. In any occasion when a person whines of feeling exceedingly disappointed, desperate or doomed, the term depression is used to tag this idiosyncratic state. Depression is not same as feeling sad and gloomy. It is not a sign of personal feebleness or a complaint that can be craved or desired (Barlow and Durand, 2001).

Timothy (2001) has anticipated that procrastination is principally a manner arrangement of delay, ensuing a subnormal interactive creation, concerning a task that is supposed by the procrastinator as being important to accomplish and causing a state of emotional upset. Timothy (2001) demonstrated that Procrastination is one of the most common and deadliest of diseases and its toll on success and happiness is heavy.

According to Ferrari (2007) procrastination is when a person lingers on important chores that are compulsory in any occupation or in any task to get desired goals and Depression is emotional terminology that "almost freezes" an individual to stuck on in every matter of life. Procrastination can be overwhelmed through a minor alteration of mannerism and thinking approaches, depression is mainly concerned with exhaustion, moods of desperateness, rage and of poor selfconcept. Both terms have a common phenomenon that procrastination is sometimes a momentary condition, but depression is somewhat that takes a great deal of time and energy to overcome. Noticing individual procrastination demands time to overwhelm. Both mental states have the consequence of "checking down" the motivation of an individual. Eradication of these destructive conditions of mind has to come off for an employer to be mostly functioning.

Kimberly (2007) described that the lifestyle, habits, parents, etc. of the depressed people are totally excluded. They really upset of the way their life is going on. They have lack of motivation and desire to do anything. They delay their every task because they find no pleasure in their life. Kimbley (2007) 
described that depressive patients lack the love and compassion that they expect from a lot of people, they lack the attention from friends and family and with their parents constantly badgering them and they lose the interest in whatever work they tell them or they tell themselves. Their family barely calls to talk with them. Their parents constantly badger them, have problems of their own, and act depressive around them too which rubs off on them. They've managed to remain sane, and proper, and do the bare minimum to keep them in check and not go crazy. They lack the discipline, commitment, motivation to strive for the goals, and patience.

Overall negativity is a very noteworthy cognitive depression indication. Individuals are typically persuaded that nothing can be ever good for them in their life span, and they normally become deserted to alter any phase of it. Since they have an inclination to suppose the poorest, they probably procrastinate and are underachievers. Most are prone to moods of desperateness and powerlessness that lead them to the risk of suicidal thinking (Michalak et al., 2009). A protruding cognitive indication of depression is pessimism. Individuals are typically persuaded that nothing can progress and they assume themselves abandoned to alter any side of life. They expect the nastiest; they are expected to procrastinate (Comer, 2001).

According to Alexandria (2006) depression and procrastination are merely a message, through subconscious mind, reporting that everything is demolished. Dare, do and discover a manner to respond to subconscious mind and depression will vanish. Each minor footstep an individual takes to deal with depression can restore certain amount of his usual vigor and alternatively some motivation.

According to Michalak et al. (2009) depressed individuals commonly believe that their reasoning skills are poor. They may sense misperception and a helplessness to recall things. They are simply diverted and are incapable to resolve minor issues. Researchers have found out that individuals with depression signs accomplish much poor than non-depressed individuals in memory tasks, attention span and reasoning skills. This is cause of the deficiency of motivation that individuals practice while depressed. They sense sadness and sorrow in their routine life and feel exhausted.

The purpose of present study is to assess the relationship between depression and procrastination among clinically diagnosed depressive individuals and individuals 
from general population. Many researches have been conducted to find out its theories, types and effects in their life. Up till now in Pakistan very few researches and surveys have been conducted on the procrastinated behavior of depressed patients. Procrastination is considered as a very private issue and no body admits that he or she delays their work. In Pakistan little attention has been carried out to the relationship between depression and procrastination. Researcher wants to explore procrastination level among clinically diagnosed depressed individuals and individuals from general population in three big cities of Punjab province. In western countries a lot of researches have been made on procrastination in depressed patients but in east and especially in Pakistan this research is not made before. So the research is significant in finding out the outcome of this study.

\section{OBJECTIVES OF THE STUDY}

The present study has the following major objectives:

1. To find out and compare the level of depression and procrastination among clinically diagnosed depressive patients and general population living in Punjab, Province.

2. To find out the relationship between depression and procrastination for making conclusion about causes of depression.

\section{QUESTIONS OF STUDY}

Following are the questions of the present study:

1. The level of depression and procrastination existing among general population and does it differ from the clinically diagnosed patients based on different constructs?

2. Is there significant relationship between depression and procrastination?

\section{METHODOLOGY}

\section{Population and sample}

Population of the study was people living in three big cities of Punjab province (Lahore, Multan and Faisalabad). Sample of the study comprised of $N=240$ individuals $(n=120$ clinically diagnosed depressive individuals and $n=120$ individuals from general population $(60=$ male and $60=$ female $)$ 
There were $n=60$ male and $n=60$ female in each sample. The data was collected from different hospitals and residential areas of Multan, Faisalabad and Lahore city. These individuals belonged to different age groups varying from 15 to 45 years of age.

\section{INSTRUMENTS}

Following were the instruments used for the current study to collect the data.

Procrastination Scale: The procrastination scale was developed by Tuck man (1991). The original scale consisted of 35 items designed to assess procrastination. For the present investigation, the computed Cronbach's Alpha reliability for the resulting 16 items scale was 0.86 . The scale is a Likert type Scale with four responses categories which are as follows as 4 $=$ that's for me sure ; 3 that's my tendency ;2 that's not my tendency; $1=$ that's not me for sure. Results from various studies yield a high internal consistency of procrastination scale. The Alpha reliability was found to be 0.60 .

\section{BECK DEPRESSION INVENTORY}

Beck depression inventory (BDI) was designed by Aaron.T.Beck (1971) for measuring the intensity of depression in individuals. Scoring is produced by single score indicating intensity of the depressive episode in which time is not reported for filling the questionnaire. The BDI is a 21 item self-rating scale. The inventory consists of 21 symptoms and attitudes which could be rated from 0 to 3 in terms of intensity. Reliability of BDI is .86

\section{RESULTS}

Table No. 1: Depression is positively correlated with procrastination among depressed individuals and individuals from general population.

\begin{tabular}{cccc}
\hline Samples & N & $\begin{array}{c}\text { Correlati } \\
\text { on }\end{array}$ & $\begin{array}{c}\text { p-- } \\
\text { value }\end{array}$ \\
\hline $\begin{array}{c}\text { Depression in Depressed } \\
\text { individuals }\end{array}$ & $\begin{array}{c}12 \\
0\end{array}$ & 0.316 & 0.000 \\
$\begin{array}{c}\text { Procrastination in Depressed } \\
\text { individuals }\end{array}$ & $\begin{array}{c}12 \\
0\end{array}$ & & \\
Depression in general population & 12 & -0.101 & 0.274 \\
& 0 & & \\
\hline
\end{tabular}




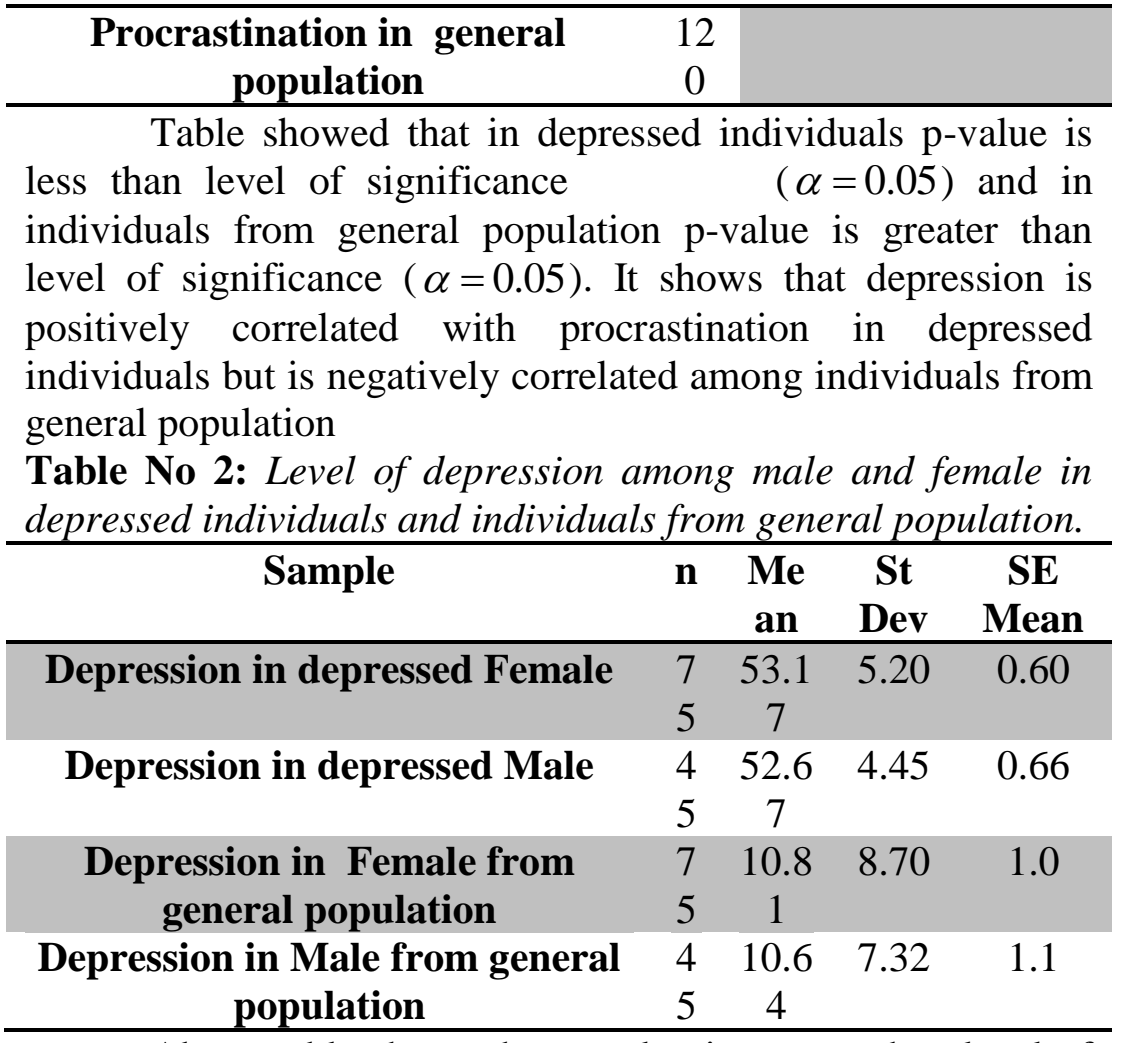

Above table shows that $\mathrm{p}$-value is greater than level of significance $(\alpha=0.05)$ among both samples, therefore, we concluded that level of depression is low among females as compared to males in depressed individuals and individuals from general population.

Table No 3. Level of depression among married and unmarried individuals in depressed and non-depressed individuals.

\begin{tabular}{|c|c|c|c|c|}
\hline Samples & $\mathbf{n}$ & $\begin{array}{l}\text { Me } \\
\text { an }\end{array}$ & $\begin{array}{c}\text { St } \\
\text { Dev }\end{array}$ & $\begin{array}{c}\text { SE } \\
\text { Mean }\end{array}$ \\
\hline Depression in depressed married & $\begin{array}{l}9 \\
1\end{array}$ & $\begin{array}{l}53 . \\
22\end{array}$ & 4.80 & 0.50 \\
\hline $\begin{array}{c}\text { Depression in depressed } \\
\text { unmarried }\end{array}$ & $\begin{array}{l}2 \\
9\end{array}$ & $\begin{array}{l}52 . \\
24\end{array}$ & 5.28 & 0.98 \\
\hline $\begin{array}{l}\text { Depression in married from } \\
\text { general population }\end{array}$ & $\begin{array}{l}3 \\
4\end{array}$ & $\begin{array}{l}11 . \\
03\end{array}$ & 6.86 & 1.2 \\
\hline $\begin{array}{l}\text { Depression in unmarried from } \\
\text { general population }\end{array}$ & $\begin{array}{l}8 \\
6\end{array}$ & $\begin{array}{l}10 . \\
64\end{array}$ & 8.68 & 0.9 \\
\hline
\end{tabular}

Table showed that among married and unmarried individuals from both samples p-value is greater than level of significance ( $\alpha=0.05$ ), therefore, it is concluded that level of depression is high among married as compared to unmarred individuals in both samples. 
Table No 4: Level of procrastination is high in females as compare to the males in depressed individuals and individuals from general population.

\begin{tabular}{|c|c|c|c|c|}
\hline Samples & $\mathbf{N}$ & $\begin{array}{l}\text { Me } \\
\text { an }\end{array}$ & $\begin{array}{c}\text { St } \\
\text { Dev }\end{array}$ & $\begin{array}{c}\text { SE } \\
\text { Mean }\end{array}$ \\
\hline Procrastination in Female & 7 & 51. & 6.55 & 0.76 \\
\hline Depressed & 5 & 59 & & \\
\hline Procrastination in male Depressed & $\begin{array}{l}4 \\
5\end{array}$ & $\begin{array}{l}49 . \\
47\end{array}$ & 7.22 & 1.10 \\
\hline $\begin{array}{l}\text { Procrastination in Female from } \\
\text { general population }\end{array}$ & $\begin{array}{l}7 \\
5\end{array}$ & $\begin{array}{l}42 . \\
44\end{array}$ & 8.82 & 1.0 \\
\hline $\begin{array}{c}\text { Procrastination in male from } \\
\text { general population }\end{array}$ & $\begin{array}{l}4 \\
5 \\
\end{array}$ & $\begin{array}{l}45 . \\
38\end{array}$ & 8.09 & 1.2 \\
\hline \multicolumn{5}{|c|}{$\begin{array}{l}\text { Table showed that in both samples the level of } \\
\text { procrastination in males and females, p-value is greater than } \\
\text { level of significance }(\alpha=0.05) \text { therefore it is concluded that } \\
\text { level of procrastination is low in females as compared to males } \\
\text { in individuals from both samples. }\end{array}$} \\
\hline
\end{tabular}

Table No 5: Level of procrastination is high among unmarried individuals as compare to the married in depressed individuals and individuals from general population.

\begin{tabular}{|c|c|c|c|c|}
\hline Samples & $\mathbf{N}$ & $\begin{array}{l}\text { Me } \\
\text { an }\end{array}$ & $\begin{array}{c}\text { St } \\
\text { Dev }\end{array}$ & $\begin{array}{c}\text { SE } \\
\text { Mean }\end{array}$ \\
\hline $\begin{array}{c}\text { Procrastination in unmarried } \\
\text { depressed }\end{array}$ & $\begin{array}{l}2 \\
9\end{array}$ & 51. & 7.58 & 1.4 \\
\hline $\begin{array}{c}\text { Procrastination in married } \\
\text { depressed }\end{array}$ & $\begin{array}{l}9 \\
1\end{array}$ & $\begin{array}{l}50 . \\
60\end{array}$ & 6.64 & 0.7 \\
\hline $\begin{array}{l}\text { Procrastination in unmarried from } \\
\text { general population }\end{array}$ & $\begin{array}{l}3 \\
4\end{array}$ & $\begin{array}{l}42 . \\
88\end{array}$ & 7.31 & 1.30 \\
\hline $\begin{array}{c}\text { Procrastination in married from } \\
\text { general population }\end{array}$ & $\begin{array}{l}8 \\
6 \\
\end{array}$ & $\begin{array}{l}43 . \\
80\end{array}$ & 9.14 & 0.99 \\
\hline $\begin{array}{l}\text { Table showed that in both } \\
\text { unmarried individuals p-value is } \\
\text { significance }(\alpha=0.05) \text { therefore it is } \\
\text { procrastination is low among unma } \\
\text { married in depressed individuals and } \\
\text { population. }\end{array}$ & & iples & $\begin{array}{l}\text { marrie } \\
\text { an le }\end{array}$ & $\begin{array}{l}\text { ed and } \\
\text { vel of } \\
\text { evel of } \\
\text { red to } \\
\text { general }\end{array}$ \\
\hline
\end{tabular}

\section{FINDINGS}

It is found out in this study that depression is positively correlated with depression in depressed individuals but is negatively correlated among individuals from general population. Results of current study also showed that level of depression is low among females as compared to males in 
depressed individuals and individuals from general population and the level of depression is high among married as compared to un-marred in depressed individuals' females as compared to males in depressed individuals and individuals from general population.

\section{CONCLUSION}

We can conclude from the findings of this comparative study that as procrastination is positively correlated with depression among depressed individuals, health professionals should work towards the time management skills of the individuals to escape from procrastination and for being the active, punctual and healthy members of society. The results of this study showed that as there is positive correlation between depression and procrastination among depressed individuals but negative correlation between both construct among individuals from general population, it shows that individuals from general population manage their procrastination habit and do not fall in depression due to their procrastination habit but depressed individuals do suffer from depression due to their procrastination habit.

The findings of this study also showed that depression and procrastination both are high in male samples and in married samples. It can be concluded from these findings that health practitioners and other individuals working on mental illness should treat all patients differently and they should practice different psychotherapeutic techniques for married and unmarried and also for male or female individuals.

\section{RECOMMENDATIONS}

1. Health department and other societies working with mental health should make arrangements for workshops and seminars related to time management issues. With the eradication of procrastination, people will be calm and easy in all their responsibilities and level of anxiety and depression will also be ruled out.

2. Psychologist should not deal with same therapies for male nd female patients or married and unmarried sample. They should seek for different psychotherapeutic techniques for every individual. 


\section{REFERENCES}

Alexandria. (2006). Depression and lack of motivation. Retrieved from http://www.2knowmyself.com/depression/Depression_a nd_lack of motivation

Barlow, D.H., and Durand, V.M. (2001). Abnormal Psychology. ( $2^{\text {nd }}$ Ed.). USA: wards worth Thomoson learning inc, 182-188.

Comer, R.J. (2006). Abnormal Psychology. (6 $6^{\text {th }}$ Ed). New York: PrincetonUniversity, 223-239

Ferrari, J. R. (2007). Frequent behavioral delay tendencies by adults international prevalence rates of chronic procrastination, Journal of Cross-Cultural Psychology, $38,(4), 458-464$

Kimberly. (2007). Dealing with Depression: no motivation, depression, long periods, Retrieved fromhttp://en.allexperts.com/q/Dealing-Depression1814/motivation-depression.htm

Michalak, J., Troje, N. F., Fischer, J., Vollmar, P., Heidenreich, T., \& Schulte, D. (2009). Embodiment of sadness and depression-gait patterns associated with dysphoric mood. Psychosomatic medicine, 71(5), 580-587.

Timothy, A. (2001)PRG: History of Procrastination, Retrieved from httpserver.carleton.ca/ tpychyl/.../research_history_term.ht $\mathrm{ml}$. 